\section{Royal Flush $^{\text {TM }}$ 'UF-18-49'-a Red Fancy-leaved Caladium for Large Containers and Sunny Landscapes}

\author{
Zhanao Deng ${ }^{1}$ and Brent K. Harbaugh \\ University of Florida, IFAS, Department of Environmental Horticulture, \\ Gulf Coast Research and Education Center, 14625 County Road 672, \\ Wimauma, FL 33598
}

Additional index words. Araceae, Caladium bicolor, Caladium $\times$ hortulanum, new cultivar, ornamental breeding

Caladiums (Caladium $\times$ hortulanum Birdsey, Araceae Juss.) are often used to provide color and a tropical ambiance to container gardening or the landscape (Evans et al., 1992). Approximately $95 \%$ of the caladium tubers used in the United States and worldwide are produced in Florida. Red fancyleaved cultivars accounted for $23 \%$ of the acreage planted by Florida caladium growers (Bell et al., 1998). 'Freida Hemple' (33\%) and 'Postman Joyner' (13\%) accounted for nearly half of the red fancy-leaved cultivars commercially grown. 'Florida Cardinal', released from the University of Florida caladium breeding program in 1988 (Wilfret, 1988), comprised $7 \%$ of the red fancy-leaved cultivars grown. It was selected primarily for use in containers because it produces many leaves without the need to de-eye tubers. Recently, 'Freida Hemple' was found highly susceptible to fusarium tuber rot, the most important disease that affects caladium tuber quality (Goktepe et al., 2007). 'Postman Joyner' and 'Florida Cardinal' were also susceptible to fusarium tuber rot (Goktepe et al., 2007). Therefore, there was a strong need for new red fancy-leaved caladium cultivars. Royal Flush ${ }^{\mathrm{TM}}$ 'UF-18-49' is a new red fancy-leaved cultivar that has been selected for its vigor, tall stature, large leaf size, and sun tolerance. It has shown outstanding performance in container forcing and landscape planting trials in Florida, and it was selected as "Best of the Best" in the 2013 Ohio State University cultivar trials (Dolce, 2013; Pangborn and Pasian, 2013).

\section{Origin}

Royal Flush ${ }^{\mathrm{TM}}$ 'UF-18-49' (Fig. 1) was selected in 2001 out of progeny from a cross between UF-702 and 'Red Flash' (Fig. 2). UF-702 was a breeding line derived from

\footnotetext{
Received for publication 21 May 2014. Accepted for publication 20 June 2014

We thank Joyce Jones, Gail Bowman, Rick Kelly, and Nancy West for their excellent technical support.

${ }^{1}$ To whom reprint requests should be addressed; e-mail zdeng@ufl.edu.
}

a cross between an unnamed sport of 'Aaron' and UF-FCB, a breeding line resulting from the cross 'Fire Chief' $\times$ 'Buck'. 'Red Flash' and 'Aaron' are major commercial cultivars known for their attractive leaf colors, strong plant vigor, good sun tolerance, high tuber yields, and large tuber sizes (Bell et al., 1998; Deng et al., 2011). 'Fire Chief' and 'Buck' are commercially produced on a much smaller scale, but they carry unique characteristics: the former produces red translucent leaves and the latter deep dark red leaves. The ancestries of 'Aaron', 'Fire Chief', 'Red Flash', and 'Buck' are unknown.

\section{Description}

Descriptions of color [e.g., Royal Horticultural Society (RHS) 200B] for plant parts are based on comparison with the Royal Horticultural Society Color Chart (RHS, 1986). Plants used for describing leaf characteristics and color were grown in $20.3-\mathrm{cm}$ containers in $\mathrm{a} \approx 30 \%$ shaded greenhouse from intact No. 1 (3.8 to $6.4 \mathrm{~cm}$ in diameter) tubers.

Leaves of Royal Flush ${ }^{\mathrm{TM}}$ 'UF-18-49' are peltate, sagitate-cordate, with palmate-pinnate venation. Primary and secondary veins are red (RHS 53B to 53D). The upper surface has a green (RHS 137A) margin, up to $15 \mathrm{~mm}$ wide, bordering the entire leaf except for the basal leaf sinus where it is grayed purple (RHS 187B). Interveinal areas and the primary veins in the center of the leaf blade are grayed purple (RHS 187B). The undersurface is primarily a grayed green (RHS 191A) with red-purple (RHS 60A and 60B) primary veins. Petioles are 4 to $7 \mathrm{~mm}$ in diameter and are grayed purple (RHS 187A) to black (RHS 202A). Tuber surfaces are brown (RHS 200C-D) with the cortical area yellow (RHS 10B). Jumbo tubers are multisegmented, usually bearing three to five dominant buds.

\section{Performance}

Royal Flush ${ }^{\mathrm{TM}}$ 'UF-18-49' was evaluated for tuber production and plant performance at the Gulf Coast Research and Education
Center in Wimauma, FL, in 2005 and 2006. The soil was an EauGallie fine sand with $1 \%$ organic matter and a $\mathrm{pH}$ of 6.2. Plants were grown in a plastic-mulched raised-bed system maintaining a constant water table with seep irrigation (Geraldson et al., 1965). For the 2005 evaluation, ground beds were fumigated on 25 Feb. 2005 (6 weeks before planting) with a mixture of $67 \%$ methyl bromide and 33\% chloropicrin (by volume) at the rate of $392 \mathrm{~kg} \cdot \mathrm{ha}^{-1}$. For the 2006 evaluation, ground beds were fumigated on 10 Mar. 2006, $10 \mathrm{~d}$ before planting, with the same fumigant mixture but at the half rate, $196 \mathrm{~kg} \cdot \mathrm{ha}^{-1}$. The ground beds were $91 \mathrm{~cm}$ wide and $20 \mathrm{~cm}$ high, and caladium seed pieces (cut tuber propagules, $\approx 2.5 \mathrm{~cm}$ ) were planted $15 \mathrm{~cm}$ apart in three rows. Controlled-release fertilizer Osmocote $18 \mathrm{~N}-2.6 \mathrm{P}-10 \mathrm{~K} \quad(8-9$ months; Scotts Co., Marysville, $\mathrm{OH}$ ) was applied to the bed surface when caladium shoot tips emerged from the soil with nitrogen at $336 \mathrm{~kg} \cdot \mathrm{ha}^{-1}$.

Field plots were organized in three randomized complete blocks, and each plot was $1.25 \mathrm{~m}^{2}$ with 30 plants. In 2005 , seed tuber pieces were planted in April and new tubers were harvested in November; in 2006, seed pieces were planted in April and new tubers were harvested in December. Newly harvested tubers were washed and dried before they were weighed, graded, and counted per plot. Tubers were graded into five categories by their diameter: No. 2 (2.5 to $3.8 \mathrm{~cm}$ ), No. 1 (3.8 to $6.4 \mathrm{~cm})$, Jumbo (6.4 to $8.9 \mathrm{~cm})$, Mammoth $(8.9$ to $11.4 \mathrm{~cm})$, and Super Mammoth (greater than $11.4 \mathrm{~cm}$ ). The production index, an indicator of economic value of the harvested tubers, was calculated as: $\mathrm{N}($ No. 2$)+2 \mathrm{~N}$ (No. 1) $+4 \mathrm{~N}$ (Jumbo) $+6 \mathrm{~N}$ (Mammoth) $+8 \mathrm{~N}$ (Super Mammoth), where $\mathrm{N}=$ number of tubers in each grade. An analysis of variance was conducted using the GLM procedure in the SAS program (SAS Institute, 2009) to compare the performance of Royal Flush ${ }^{\mathrm{TM}}$ 'UF-18-49' with that of 'Florida Cardinal', 'Freida Hemple', and 'Postman Joyner'. The latter cultivars are important commercial red fancy-leaved caladium cultivars.

Royal Flush ${ }^{\mathrm{TM}}$ 'UF-18-49' was significantly more productive by several measures of performance than all the commercial cultivars in 2005 . The tuber weight was $18 \%$ to $56 \%$ greater, number of marketable tubers $27 \%$ to $40 \%$ more, and production index $25 \%$ to $77.8 \%$ higher than the other red cultivars (Table 1). In 2006, Royal Flush ${ }^{\mathrm{TM}}$ 'UF-18-49' was comparable to 'Florida Cardinal', 'Freida Hemple', and 'Postman Joyner' in tuber weight, number of marketable tubers, and production index, except that its number of marketable tubers was smaller than that of 'Freida Hemple'. The size distribution of tubers produced by Royal Flush ${ }^{\mathrm{TM}}$ 'UF-18-49' was similar in 2005 and 2006 growing seasons: $\approx 60 \%$ of the tubers were graded as No. 1 and Jumbo, and $\approx 20 \%$ were in the Mammoth size.

Landscape performance under full-sun conditions was evaluated in 2005 and 2006 


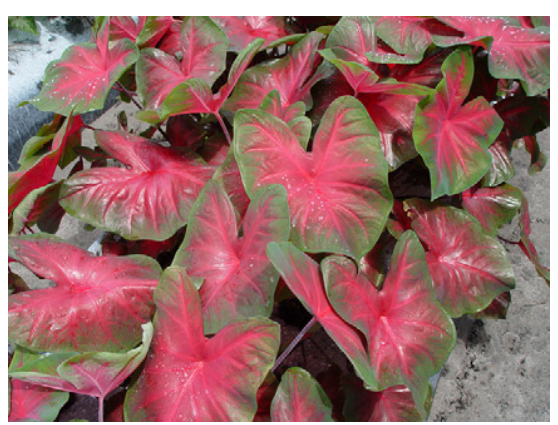

Fig. 1. Royal Flush ${ }^{\mathrm{TM}}$ 'UF-18-49' plants (4 months old) grown in full sun in Wimauma, FL. on the same plots used for evaluating tuber production. The overall plant performance was rated in two growing seasons on a scale of 1 to 5 with 1 being very poor (few leaves and lack of vigor) and 5 being excellent (full plants, numerous leaves, and bright color display). Leaf sunburn tolerance was also evaluated in each growing season on a scale of 1 to 5 with 1 being very susceptible to sunburns and showing numerous sun-damaged areas or holes on leaves and 5 being resistant to sunburns and not showing any sun-damaged areas. At $\approx 4$ months after planting, plant height, number of leaves, and foliar characteristics were measured.

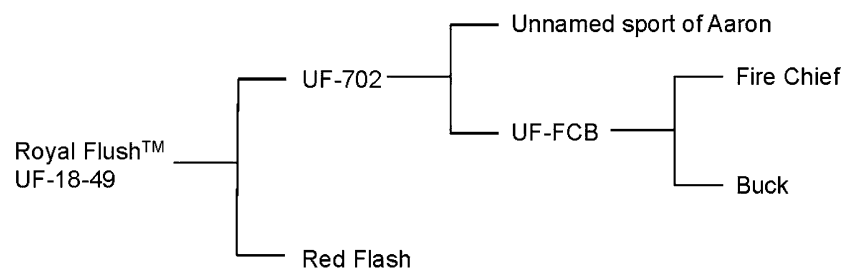

Fig. 2. Pedigree of Royal Flush ${ }^{\mathrm{TM}}$ 'UF-18-49' caladium.

Table 1. Tuber weight, production index, number, and grade distribution of four caladium cultivars grown in Wimauma, FL (2005 and 2006). ${ }^{2}$

\begin{tabular}{|c|c|c|c|c|c|c|c|c|}
\hline \multirow[b]{2}{*}{ Cultivar } & \multicolumn{3}{|c|}{ Tuber } & \multicolumn{5}{|c|}{ Tuber distribution $^{y}(\%)$} \\
\hline & $\overline{\mathrm{Wt}(\mathrm{kg})}$ & Production index $x^{x}$ & Marketable (no.) & Super mammoth & Mammoth & Jumbo & No. 1 & No. 2 \\
\hline Royal Flush ${ }^{\mathrm{TM}}$ UF-18-49 & $3.9 \mathrm{a}^{\mathrm{w}}$ & $160 \mathrm{a}$ & $44.4 \mathrm{a}$ & $6.0 \mathrm{a}$ & $18.0 \mathrm{NS}$ & $32.7 \mathrm{NS}$ & $30.7 \mathrm{NS}$ & $12.7 \mathrm{Ns}$ \\
\hline \multirow[t]{2}{*}{ Postman Joyner } & $2.5 \mathrm{c}$ & $90 \mathrm{~d}$ & $31.7 \mathrm{~b}$ & $0 \mathrm{~b}$ & 10.0 & 27.0 & 54.3 & 9.3 \\
\hline & & & & Year 2006 & & & & \\
\hline Freida Hemple & 5.2 & 159 a & $48.8 \mathrm{a}$ & 6.0 & $17.3 \mathrm{~b}$ & $22.0 \mathrm{ab}$ & 35.3 & 18.7 \\
\hline Postman Joyner & 3.8 & $115 \mathrm{~b}$ & $36.6 \mathrm{~b}$ & 2.7 & $27.0 \mathrm{ab}$ & $13.0 \mathrm{~b}$ & 42.7 & 18.7 \\
\hline
\end{tabular}

${ }^{\mathrm{z}}$ Values presented are means of three replicates with 30 propagules planted in a plot.

'Tubers graded into five categories by maximum tuber diameter: No. 2 (2.5 to $3.8 \mathrm{~cm})$, No. 1 (3.8 to $6.4 \mathrm{~cm})$, Jumbo (6.4 to $8.9 \mathrm{~cm})$, Mammoth (8.9 to $11.4 \mathrm{~cm})$, and Super Mammoth (greater than $11.4 \mathrm{~cm}$ ). Tuber distribution data $(\%)$ were transformed using the formula arcsine [square root (percentage/00)] before analysis of variance and mean separation.

${ }^{x}$ The production index is an indicator of economic value of the tubers harvested and is calculated as follows: N (No. 2) $+2 \mathrm{~N}(\mathrm{No} .1)+4 \mathrm{~N}(\mathrm{Jumbo})+6 \mathrm{~N}$ (Mammoth) $+8 \mathrm{~N}$ (Super Mammoth), where $\mathrm{N}=$ number of tubers in each grade.

wMean separation within column by Fisher's least significant difference test at $P \leq 0.05$. Mean values with the same letter within column are not statistically different.

NS Nonsignificantly different by $\mathrm{F}$ test at $P=0.05$.

Table 2. Plant characteristics, performance and sun tolerance from planting 2.54-cm caladium tuber propagules in ground beds in full sun in Wimauma, FL (2005 and 2006). ${ }^{\mathrm{z}}$

\begin{tabular}{|c|c|c|c|c|c|c|c|c|c|c|c|c|c|c|}
\hline \multirow{2}{*}{ Cultivar } & \multirow{2}{*}{ Plant ht ${ }^{\mathrm{y}}(\mathrm{cm})$} & & & & \multicolumn{5}{|c|}{ Performance rating $^{x}$} & \multicolumn{5}{|c|}{ Sun tolerance rating } \\
\hline & & \multicolumn{3}{|c|}{ Leaf } & \multicolumn{3}{|c|}{2005} & \multicolumn{2}{|c|}{2006} & \multicolumn{3}{|c|}{2005} & \multicolumn{2}{|c|}{2006} \\
\hline Royal Flush ${ }^{\mathrm{TM}}$ UF-18-49 & $51.3 \mathrm{a}^{\mathrm{v}}$ & $19.9 \mathrm{ab}$ & $32.3 \mathrm{a}$ & $21.2 \mathrm{a}$ & $4.0 \mathrm{a}$ & $4.8 \mathrm{a}$ & $4.8 \mathrm{a}$ & $4.3 \mathrm{a}$ & $4.5 \mathrm{a}$ & $2.6 \mathrm{bc}$ & $3.9 \mathrm{a}$ & $4.6 \mathrm{a}$ & $4.0 \mathrm{a}$ & $4.3 \mathrm{a}$ \\
\hline Freida Hemple & $43.5 \mathrm{~b}$ & $23.4 \mathrm{a}$ & $26.3 \mathrm{~b}$ & $17.7 \mathrm{~b}$ & $3.3 \mathrm{~b}$ & $4.5 \mathrm{a}$ & $4.2 \mathrm{~b}$ & $4.2 \mathrm{a}$ & $4.4 \mathrm{a}$ & $2.7 \mathrm{~b}$ & $4.0 \mathrm{a}$ & $3.6 \mathrm{~b}$ & $3.8 \mathrm{a}$ & $3.9 \mathrm{~b}$ \\
\hline Postman Joyner & $35.7 \mathrm{c}$ & $13.4 \mathrm{~b}$ & $26.8 \mathrm{~b}$ & $16.4 \mathrm{bc}$ & $1.6 \mathrm{c}$ & $2.0 \mathrm{~b}$ & $2.8 \mathrm{c}$ & $2.2 \mathrm{~b}$ & $2.6 \mathrm{~b}$ & $3.9 \mathrm{a}$ & $2.5 \mathrm{~b}$ & $3.8 \mathrm{~b}$ & $2.3 \mathrm{~b}$ & $3.5 \mathrm{c}$ \\
\hline
\end{tabular}

${ }^{2}$ Values presented for plant height, leaf number, length, and width are means of three replicates with three plants measured per plot per year, whereas performance and sunburn tolerance ratings are means of three replicates based on whole plot evaluation.

${ }^{y}$ Data were taken over two growing seasons (2005 and 2006), $\approx 4$ months. (Aug. 2005 and 2006) after tubers were planted in April each year.

xPlants were rated on a scale of 1 to 5, with 1 being very poor, 3 fair and acceptable, and 5 being excellent in plant vigor, fullness, and color display, in July, Aug., and Sept. 2005 and Aug. and Sept. 2006, respectively.

"Plants' sunburn tolerance was rated on a scale of 1 to 5 with 1 being very poor, 3 fair and acceptable, and 5 being excellent without showing any signs of leaf burns or resulted holes on leaf surfaces taken in July, Aug., and Sept. 2005 and Aug. and Sept. 2006, respectively.

'Mean separation within column by Fisher's least significant difference test at $P \leq 0.05$. Mean values with the same letter within column are not statistically different. 
Table 3. Plant performance for caladium cultivars grown from No. 1 tubers in 11.4 -cm containers in a $45 \%$ shaded glasshouse in Wimauma, FL, in $2006 .{ }^{\mathrm{z}}$

\begin{tabular}{|c|c|c|c|c|c|c|c|c|c|c|c|c|}
\hline \multirow[b]{2}{*}{ Cultivar } & \multicolumn{2}{|c|}{ Days to sprout ${ }^{y}$} & \multicolumn{2}{|c|}{ Plant ht $(\mathrm{cm})$} & \multicolumn{2}{|c|}{ Leaves (no.) } & \multicolumn{2}{|c|}{ Leaf length $(\mathrm{cm})$} & \multicolumn{2}{|c|}{ Leaf width $(\mathrm{cm})$} & \multicolumn{2}{|c|}{ Quality rating } \\
\hline & Intact & De-eye & Intact & De-eye & Intact & $\overline{\text { De-eye }}$ & Intact & De-eye & Intact & De-eye & Intact & De-eye \\
\hline Royal Flush ${ }^{\mathrm{TM}}$ UF-18-49 & $30.3 \mathrm{a}^{\mathrm{x}}$ & $29.8 \mathrm{ab}$ & $40.5 \mathrm{a}$ & $37.9 \mathrm{a}$ & $9.0 \mathrm{~b}$ & $9.9 \mathrm{c}$ & $28.0 \mathrm{a}$ & $22.6 \mathrm{a}$ & $20.4 \mathrm{a}$ & $16.4 \mathrm{a}$ & $3.9 \mathrm{a}$ & $4.2 \mathrm{a}$ \\
\hline Florida Cardinal & $28.3 \mathrm{ab}$ & $32.9 \mathrm{a}$ & $33.0 \mathrm{~b}$ & $28.4 \mathrm{~b}$ & $13.1 \mathrm{a}$ & $17.0 \mathrm{~b}$ & $23.6 \mathrm{~b}$ & $17.8 \mathrm{~b}$ & $16.8 \mathrm{~b}$ & $11.8 \mathrm{~b}$ & $2.5 \mathrm{~b}$ & $3.3 \mathrm{~b}$ \\
\hline Freida Hemple & $24.6 \mathrm{~b}$ & $25.1 \mathrm{c}$ & $29.8 \mathrm{~b}$ & $34.9 \mathrm{a}$ & $16.3 \mathrm{a}$ & $21.0 \mathrm{a}$ & $23.3 \mathrm{~b}$ & $17.8 \mathrm{~b}$ & $17.1 \mathrm{~b}$ & $12.1 \mathrm{~b}$ & $3.8 \mathrm{a}$ & $4.1 \mathrm{a}$ \\
\hline Postman Joyner & $25.9 \mathrm{~b}$ & $27.6 \mathrm{bc}$ & $33.1 \mathrm{~b}$ & $36.1 \mathrm{a}$ & $8.1 \mathrm{~b}$ & $9.4 \mathrm{c}$ & $24.5 \mathrm{~b}$ & $19.0 \mathrm{~b}$ & $17.1 \mathrm{~b}$ & $13.1 \mathrm{~b}$ & $2.5 \mathrm{~b}$ & $3.5 \mathrm{~b}$ \\
\hline
\end{tabular}

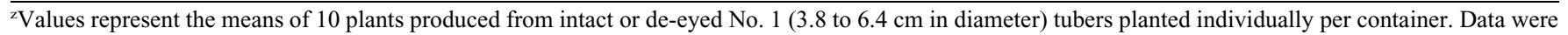
taken 8 weeks after planting.

${ }^{y}$ Number of days from planting to the first unfurled leaf.

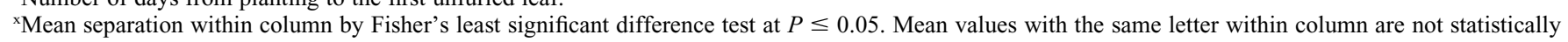
different.

comparing growth parameters with the same three cultivars used in field tests. No. 1 tubers were planted either intact or de-eyed in a peat/vermiculite mix (VerGro Container Mix A; Verlite, Tampa, FL) on 3 Apr. 2006. The study was conducted in a greenhouse with $45 \%$ light exclusion during the summer in Wimauma, FL. Daily temperatures ranged from a low of $16^{\circ} \mathrm{C}$ at night to 29 ${ }^{\circ} \mathrm{C}$ during the day during the experiment. Potted plants were arranged on metal benches in the greenhouse in a randomized complete block design with 10 replications. Plant height, number of leaves, and foliar characteristics were recorded 8 to 10 weeks after planting.

Royal Flush ${ }^{\mathrm{TM}}$ 'UF-18-49' sprouted $\approx 30 \mathrm{~d}$ after planting either intact or de-eyed tubers and was similar to 'Florida Cardinal' in sprouting time in container forcing but $\approx 5 \mathrm{~d}$ later than 'Freida Hemple' and $\approx 2$ to $4 \mathrm{~d}$ later than 'Postman Joyner' (Table 3). When tubers were planted intact, Royal Flush ${ }^{\mathrm{TM}}$ 'UF-18-49' plants were the tallest with a height of $40.5 \mathrm{~cm}, 7$ to $10 \mathrm{~cm}$ taller than the other red cultivars. When tubers were de-eyed before planting, no significant differences in height were observed among Royal Flush ${ }^{\mathrm{TM}}$ 'UF-18-49', 'Freida Hemple', and 'Postman Joyner'. Leaves of Royal Flush $^{\mathrm{TM}}$ 'UF-18-49' were again longer (3 to $5 \mathrm{~cm}$ ) and wider ( 3 to $5 \mathrm{~cm}$ ) than the leaves of the checks, regardless of tuber treatment (intact or de-eyed). Royal Flush ${ }^{\mathrm{TM}}$ 'UF-18-49' was similar to 'Postman Joyner' in leaf development, producing eight to 10 leaves within 8 weeks after planting. Royal Flush $^{\mathrm{TM}}$ 'UF-18-49' and 'Postman Joyner' produced fewer leaves than 'Florida Cardinal' and 'Freida Hemple'. Pot plant quality ratings of Royal Flush ${ }^{\mathrm{TM}}$ 'UF-18-49' were above 4.0, higher than that of 'Florida Cardinal' and 'Postman Joyner' and similar to that of 'Freida Hemple'.

\section{Recommendation}

Plants of Royal Flush ${ }^{\mathrm{TM}}$ 'UF-18-49' are vigorous with large leaves that are bright and attractive even when grown in full sun. These characteristics make Royal Flush ${ }^{\mathrm{TM}}$ 'UF-18-49' suitable for use in the landscape (sunny or shady locations) or large containers. To force this cultivar in small containers, tubers should be de-eyed before planting. Although extensive research and evaluations of this cultivar have been performed on small acreages, tuber producers are encouraged to plant only limited quantities of Royal Flush ${ }^{\mathrm{TM}}$ 'UF-18-49' until having gained experience in producing this cultivar. Standard postharvest treatment of tubers is recommended (Harbaugh and Tjia, 1985) and pre-plant hot water treatment of tubers (Rhodes, 1964) is encouraged to prolong their life.

\section{Availability}

A plant patent has been granted for 'UF-18-49' caladium under the Plant Patent Number PP24,431. Production of this cultivar is to be with a licensing agreement with the Florida Foundation Seed Producers, Inc., P.O. Box 309, Greenwood, FL 32443. Information on tuber availability and propagation agreements can be obtained from the Florida Foundation Seed Producers, Inc. (<http://www.ffsp.net/>).

\section{Literature Cited}

Bell, M.L., G.J. Wilfret, and D.A. DeVoll. 1998. Survey of caladium tuber producers for acreage of cultivars grown. Proc. Fla. State Hort. Soc. 111:32-34

Deng, Z., B.K. Harbaugh, R.K. Schoellhorn, and R.C. Andrew. 2011.2003 Survey of the Florida caladium tuber production industry. Univ. of Fla. /IFAS extension fact sheet ENH1007. 16 July 2013. <http://edis.ifas.ufl.edu/EP258>.

Dolce, J. 2013. OSU trials: Best of the Best. GPN-Greenhouse Product News. 16 Mar. 2014. <http://www.gpnmag.com/osu-trialsbest-best $>$.

Evans, M.R., G.J. Wilfret, and B.K. Harbaugh. 1992. Caladiums as potted and landscape plants. IFAS, Univ. of Fla. Agr. Ext. Serv. Circ. 1060.

Geraldson, C.M., A.J. Overman, and J.P. Jones. 1965. Combination of high analysis fertilizers, plastic mulch and fumigation for tomato production on old agricultural land. Proc. Soil Crop Sci. Soc. Fla. 25:18-24.

Goktepe, F., S. Seijo, Z. Deng, B.K. Harbaugh, and N.A. Peres. 2007. Toward breeding for resistance to Fusarium tuber rot in caladium: Isolation technique and sources of resistance. HortScience 42:1135-1139.

Harbaugh, B.K. and B.O. Tjia. 1985. Commercial forcing of caladiums. IFAS, Univ. of Fla. Agr. Ext. Serv. Circ. 621.

Pangborn, L. and C. Pasian. 2013. OSU cultivar trials: 2013 top performing plants. 16 Mar. 2014. $<\mathrm{http}$ //ohiofloriculture.osu.edu/sites/drupalohioflori.web/files/file/2013\%20top\%20performing\%20plants\%20with\%20pics.pdf $>$.

Rhodes, H.L. 1964. Effect of hot water treatment of seed tubers and soil fumigation for control of root knot on yield of caladiums. Plant Disease Reptr. 8:568-571.

Royal Horticultural Society. 1986. RHS colour chart. Royal Hort. Soc., London, UK.

SAS Institute. 2009. The SAS system for Windows. Release 9.2. SAS Inst., Cary, NC.

Wilfret, G.J. 1988. Florida Cardinal, a red caladium for forcing. IFAS, Univ. of Fla. Agr. Exp. Stn. Circ. S-351. 